Acta vet. scand. $1977,18,367-373$.

From the State Veterinary Institute for Virus Research, Lindholm, Kalvehave, Denmark.

\title{
SAPONIN ADJUVANTS
}

\section{THE ADJUVANT ACTIVITY OF QUIL A IN TRIVALENT VACCINATION OF CATTLE AND GUINEA PIGS AGAINST FOOT-AND-MOUTH DISEASE}

By

K. Dalsgaard and Merethe H. Jensen

DALSGAARD, K. and MERETHE H. JENSEN: Saponin adjuvants. VI. The adjuvant activity of Quil $A$ in trivalent vaccination of cattle and guinea pigs against foot-and-mouth disease. Acta vet. scand. 1977, $18,367-373$. - The saponin adjuvant Quil $A$ was investigated in trivalent vaccination against foot-and-mouth disease with a concentrated vaccine based on BHK suspension cell virus of the serotypes $O$, A and $\mathrm{C}$. The activity in cattle was estimated on the basis of seroneutralizing antibodies. Five and $10 \mathrm{ml}$ doses with or without $1 \mathrm{mg}$ of Quil A were each injected into 6 animals. Seroneutralizing antibodies were estimated at regular intervals during a period of 29 weeks. The activity in guinea pigs was estimated by experimental challenge. One ml doses of serial 4-fold dilutions of the vaccine with or without $50 \mu \mathrm{g}$ of Quil A were injected into 24 groups of 20 guinea pigs. Challenge was given 3 weeks after vaccination.

It was concluded that Quil A showed adjuvant activity in cattle and guinea pigs with all the serotypes used in the trivalent vaccination.

a d juvant; saponin; FMD; vaccines; neutralizing antibodies; challenge; Quil A.

Previous investigations (Dalsgaard 1974, Dalsgaard et al. 1977) demonstrated the adjuvant activity of the saponin Quil A when used in combination with monovalent vaccination with a standard dose of FMD vaccine of different serotypes.

This paper reports on the influence of Quil A on trivalent vaccination against $F M D$ with a concentrated vaccine based on BHK suspension cell virus of the serotypes $O$ (Brugge), A (Hol- 
land) and C (Turup). Adjuvant activity was estimated by serum neutralizing antibodies in cattle as well as by challenge of guinea pigs.

\section{Animals}

\section{MATERIALS AND METHODS}

The cattle used was of the Danish breed SDM, approx. 2 years old, and weighing about $500 \mathrm{~kg}$. A total of 24 animals were applied. Guinea pigs bred at the institute, weighing $300-400 \mathrm{~g}$, were used for the challenge experiments. A total of 540 animals were applied.

\section{Vaccines}

The antigens were produced in BHK suspension cultures as described by Jensen \& S $\phi$ rensen (1975) and the vaccines prepared as alhydrogel adsorbed formalin inactivated vaccines. The vaccines were concentrated 3 times by removal of supernatant fluid after sedimentation by standing (Lei 1974). The vaccines were tested individually for innocuity and potency before mixing equal parts to make the trivalent vaccine. The serotypes used for antigen preparation were $\mathrm{O}$ (Brugge), A (Holland) and C (Turup). The standard dose for cattle of a non-concentrated trivalent vaccine is $30 \mathrm{ml}$ in Denmark. Since the trivalent vaccine used in this report was concentrated 3 folds a dose of $10 \mathrm{ml}$ was used for the cattle. A $5 \mathrm{ml}$ dose was also investigated.

The dose used for guinea pigs was $1 \mathrm{ml}$ of the trivalent vaccine.

\section{Quil A}

Quil A was prepared as described by Dalsgaard (1974) and dissolved in PBS and mixed with the trivalent vaccine. The mixture was incubated at $4^{\circ} \mathrm{C}$ with gentle stirring for $1 / 2 \mathrm{hr}$. prior to application.

\section{Vaccination of cattle}

Twenty-four animals were vaccinated by subcutaneous application of the trivalent vaccine according to the following scheme: 6 animals each received $10 \mathrm{ml}$ of the vaccine alone

\begin{tabular}{|c|c|c|c|c|c|c|}
\hline , & " & , & $5 \mathrm{ml}$, & , & ", & $"$ \\
\hline ", & " & " & $10 \mathrm{ml}$, & , & , & $+1 \mathrm{mg}$ of Quil A \\
\hline ", & , & , & $5 \mathrm{ml}$, & , & , & $+1 \mathrm{mg}$ \\
\hline
\end{tabular}




\section{Neutralization test}

Sera from all the animals were taken $2,3,4,8,12,16,21,25$ and 29 weeks after vaccination. The sera were tested individually for neutralizing antibodies against FMD by titration in tubes of primary calf kidney cells. Serial 2 -fold dilutions with 3 tubes per dilution were applied. The sera were tested for antibodies against all 3 serotypes using FMD virus propagated in calf kidney cells. The neutralizing antibody titres were calculated using the method of Kärber (Kärber 1931). Group titres were expressed as reciprocal arithmetric mean values. The significance of the difference of these values for groups receiving the same vaccine dose but with or without Quil A was computed using the t-test (Croxton 1959).

\section{Vaccination of guinea pigs}

Serial 4-fold dilutions of the trivalent vaccine were made using a dummy vaccine prepared from non-infected cell cultures. The guinea pigs were vaccinated by subcutaneous application of $1 \mathrm{ml}$ of the dilutions according to the following scheme:

$\begin{array}{ccc} & \text { vaccine only } & \text { vaccine }+50 \mu g \text { of Quil A } \\ \text { Undiluted } & 60 & 60 \\ 1: 4 & 60 & 60 \\ 1: 16 & 60 & 60 \\ 1: 64 & 60 & 60\end{array}$

\section{Challenge test}

Three weeks after vaccination all the guinea pigs were subjected to challenge by intracutaneous inoculation into 3 channels in 1 hind foot pad of guinea pig adapted virus. One third of each group ( 20 animals) was used for each of the 3 serotypes, respectively. Guinea pigs showing any sign of generalization of FMD virus infection were recorded as not protected by the vaccination.

\section{RESULTS}

The neutralizing antibody titres obtained after trivalent vaccination of cattle against FMD are shown in Table 1. The addition of $1 \mathrm{mg}$ of Quil $\mathrm{A}$ to the vaccine induced a higher level of antibodies against all 3 serotypes. The effect was significant 
T a ble 1. Assay of the adjuvant activity of Quil A in cattle using a trivalent FMD vaccine based on $B H K$ cell virus. The vaccine was given to 4 groups of 6 animals, either alone or in combination with $1 \mathrm{mg}$ of Quil A per head of cattle.

\begin{tabular}{|c|c|c|c|c|c|c|c|c|c|c|c|c|}
\hline \multirow[b]{2}{*}{ Group } & \multirow{2}{*}{$\begin{array}{l}\text { Sero- } \\
\text { type }\end{array}$} & \multirow{2}{*}{$\begin{array}{l}\text { Dose of } \\
\text { vaccine }\end{array}$} & \multirow{2}{*}{$\begin{array}{c}\text { Quil A } \\
\text { dose }\end{array}$} & \multicolumn{9}{|c|}{ Weeks after vaccination } \\
\hline & & & & 2 & 3 & 4 & 8 & 12 & 16 & 21 & 25 & 29 \\
\hline \multirow[t]{3}{*}{ I } & 0 & $5 \mathrm{ml}$ & 0 & 10 & 6 & 3 & 3 & 2 & 3 & 4 & 6 & 6 \\
\hline & $\mathbf{A}$ & $5 \mathrm{ml}$ & 0 & 2 & 9 & 6 & 9 & 5 & 6 & 10 & 9 & 6 \\
\hline & C & $5 \mathrm{ml}$ & 0 & 17 & 31 & 5 & 7 & 6 & 6 & 10 & 6 & 4 \\
\hline \multirow[t]{3}{*}{ II } & 0 & $10 \mathrm{ml}$ & 0 & 32 & 16 & 24 & 15 & 10 & 8 & 9 & 11 & 6 \\
\hline & $\mathbf{A}$ & $10 \mathrm{ml}$ & 0 & 9 & 29 & 26 & 24 & 29 & 23 & 31 & 20 & 12 \\
\hline & C & $10 \mathrm{ml}$ & 0 & 71 & 99 & 78 & 33 & 13 & 29 & 17 & 13 & 14 \\
\hline \multirow[t]{3}{*}{ III } & 0 & $5 \mathrm{ml}$ & $1 \mathrm{mg}$ & $133^{*}$ & $47^{\star}$ & $33^{\star}$ & $24^{\star}$ & $18^{\circ}$ & $14^{\circ}$ & 9 & 13 & 14 \\
\hline & $\mathbf{A}$ & $5 \mathrm{ml}$ & $1 \mathrm{mg}$ & $16^{\star}$ & $17^{\circ}$ & $25^{\star}$ & $21^{\circ}$ & 12 & 11 & 19 & 12 & 8 \\
\hline & C & $5 \mathrm{ml}$ & $1 \mathrm{mg}$ & $215^{\star}$ & $87^{\circ}$ & $80^{*}$ & $55^{\star}$ & 34 & 52 & 21 & 12 & 8 \\
\hline \multirow[t]{3}{*}{ IV } & 0 & $10 \mathrm{ml}$ & $1 \mathrm{mg}$ & $62^{\circ}$ & $46^{\circ}$ & $47^{\circ}$ & 29 & 21 & 17 & 8 & 16 & 29 \\
\hline & A & $10 \mathrm{ml}$ & $1 \mathrm{mg}$ & $35^{\star}$ & $44^{\circ}$ & $71^{\star}$ & $40^{\circ}$ & 26 & 20 & 30 & 16 & 18 \\
\hline & C & $10 \mathrm{ml}$ & $1 \mathrm{mg}$ & $241^{\star}$ & $161^{\circ}$ & $162^{\circ}$ & 59 & 31 & 114 & 46 & 18 & 26 \\
\hline
\end{tabular}

The reciprocal value of the neutralizing titre of cattle sera 2-29 weeks after vaccination, arithmetic mean value of 6 animals.

* Computed to be significantly different from the value in the corresponding group receiving no Quil $\mathrm{A}$, $(\mathrm{P} \leq 0.01)$.

- Computed to be significantly different from the value in the corresponding group receiving no Quil $\mathrm{A},(\mathrm{P} \leq 0.05)$.

after 2, 3 and 4 weeks. i.e. $P$ values were less than 0.05 or in some cases less than 0.01 . After 8 weeks or later only a few of the titres of the groups receiving Quil A were significantly higher than the corresponding groups without Quil A.

The site of injection and the rectal temperature was followed during the first week after vaccination. As reported by Dalsgaard et al. (1977) the administration of Quil A may lead to a minor reaction, but also in the present experiments the reaction was negligible.

The results of the challenge test in guinea pigs are shown in Fig. 1. It can be seen that 3 weeks after vaccination Quil A significantly increased the potency of the vaccine irrespective of the serotype of FMD. 
O-Brugge
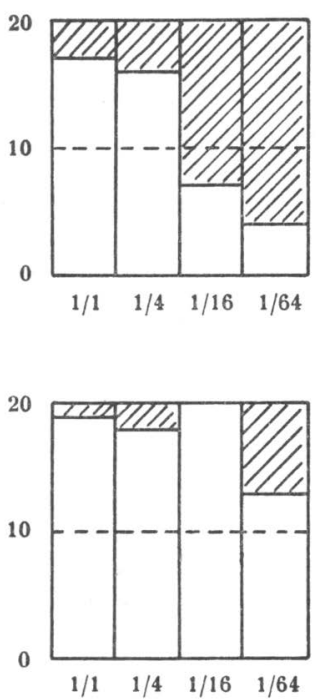

$\square$ protected

VII not protected

$1 / 1,1 / 4,1 / 16,1 / 64$ dilutions of the trivalent vaccine
A-Holland

Vaccine without Quil A

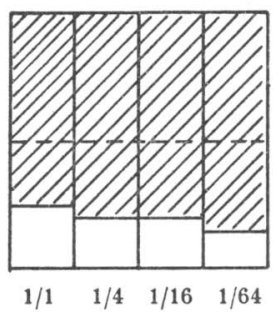

Vaccine with Quil A
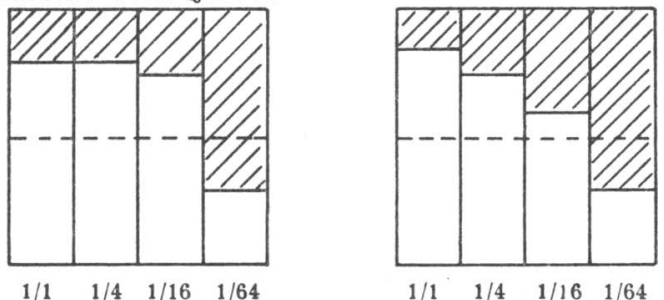

F i g u r e 1. Protection of guinea pigs against challenge.

\section{DISCUSSION}

It was shown previously that Quil A had adjuvant activity on the formation of serum neutralizing antibodies in cattle (Dalsgaard 1974, Dalsgaard et al. 1977) and on the protection of guinea pigs against challenge (Dalsgaard) when immunization with a monovalent FMD vaccine was used. In practice the simultaneous vaccination against different serotypes is often applied.

On the basis of the cattle experiment it can be seen that Quil A stimulated antibody synthesis against all the serotypes. The stimulation was not preferential for a single of the serotypes $O$, A or C. The effect of Quil A was significant during the first 4 weeks after vaccination, indicating a more rapid onset of antibody synthesis.

Another practical aspect of the administration of Quil A is the observation that Quil $A$ in combination with a $5 \mathrm{ml}$ dose generally produced a similar antibody level as a $10 \mathrm{ml}$ dose without Quil A. This possibility of dose reduction may play a role 
especially in the developing countries where the shortage of vaccine represents a major problem.

In the guinea pig experiment stimulation of immunity against all the serotypes was seen. Quil A did not preferentially stimulate any individual serotype. When Quil $\mathrm{A}$ was used, more than $50 \%$ of the animals were protected at a significantly lower antigen dose than when Quil A was omitted in the vaccination. This indicates a pronounced adjuvant activity of Quil A 3 weeks after vaccination.

It is concluded that Quil A showed adjuvant activity with all the serotypes used in a trivalent vaccination against FMD.

\section{ACKNOWLEDGEMENTS}

The challenge experiments in guinea pigs and the vaccination of cattle were performed in the department of serology. Head: Dr. K. Schjerning-Thiesen.

\section{REFERENCES}

Croxton, F. E.: Elementary Statistics, with Applications in Medicine and the Biological Sciences. Dover Publications Inc. New York 1959.

Dalsgaard, K.: Saponin adjuvants. III. Isolation of a substance from Quillaja saponaria Molina with adjuvant activity in foot-andmouth disease vaccine. Arch. ges. Virusforsch. 1974, 44, 243254.

Dalsgaard, K., Merethe H. Jensen \& K. J. Sørensen: Saponin adjuvants. IV. Evaluation of the adjuvant Quil $A$ in the vaccination of cattle against foot-and-mouth disease. Acta vet. scand. 1977, 18, $349-360$.

Jensen, Merethe H.\&F. O. Sфrensen: Concentration and cold storage of BHK 21 clone 13 suspension cells used in the large-scale production of FMD virus. Bull. Off. int. Epiz. 1975, 83, 399-406.

Kärber, G.: Beitrag zur kollektiven Behandlung pharmakologischer Reihenversuche. (Contribution to the treatment of pharmacological data). Naunyn-Schmiedeberg's Arch. exp. Path. Pharmak. 1931, 162, 480-483.

$L e i, J . C .:$ Application of polyethylene glycol in the preparation of a concentrated, purified foot-and-mouth disease vaccine. Present status for research. Bull. Off. int. Epiz. 1974, 81, 1169-1199.

\section{SAMMENDRAG}

Saponin adjuvanter. VI. Quil A's adjuvant aktivitet ved trivalent vaccination af kvæg og marsvin med mund-og klovesyge.

Saponin adjuvanten Quil A blev undersøgt i trivalent vaccination mod mund- og klovesyge med en konc. vaccine baseret på BHK suspensionscellevirus af serotyperne $\mathrm{O}, \mathrm{A}$ og $\mathrm{C}$. 
Aktiviteten i kvæg måltes ved hjælp af neutraliserende antistoffer i serum. Fem og $10 \mathrm{ml}$ doser med og uden $1 \mathrm{mg}$ Quil A injiceredes $\mathrm{i}$ hver 6 dyr. Neutraliserende antistoffer måltes med regelmæssige mellemrum over en periode på 29 uger.

Aktiviteten i marsvin måltes ved hjælp af eksperimentel smitte. En $\mathrm{ml}$ doser af 4-folds fortyndinger af vaccinen med eller uden $50 \mu \mathrm{g}$ Quil A injiceredes i 24 grupper á 20 marsvin. Dyrene udsattes for smitte 3 uger efter vaccinationen. Det konkluderedes, at Quil A havde adjuvant aktivitet både $\mathrm{i}$ kvæg og marsvin med alle 3 serotyper.

(Received April 28, 1977).

Reprints may be requested from: K. Dalsgaard, the State Veterinary Institute for Virus Research, Lindholm, DK-4771 Kalvehave, Denmark. 